\title{
Comparison of residual strength-grounding damage index diagrams for tankers produced by the ALPS/HULL ISFEM and design formula method
}

\author{
Do Kyun Kim ${ }^{1,2}$, Han Byul Kim ${ }^{1}$, Mohd Hairil Mohd ${ }^{1,3}$ and Jeom Kee Paik ${ }^{1}$ \\ ${ }^{1}$ Lloyd's Register Foundation Research Centre of Excellence \\ (The Ship and Offshore Research Institute), Pusan National University, Busan, Korea \\ ${ }^{2}$ Graduate School of Engineering Mastership, Pohang University of Science and Technology, Pohang, Korea \\ ${ }^{3}$ Maritime Technology Department, Universiti Malaysia Terengganu, Terengganu, Malaysia
}

\begin{abstract}
This study compares the Residual ultimate longitudinal strength - grounding Damage index (R-D) diagrams produced by two analysis methods: the ALPS/HULL Intelligent Supersize Finite Element Method (ISFEM) and the design formula (modified Paik and Mansour) method - used to assess the safety of damaged ships. The comparison includes four types of double-hull oil tankers: Panamax, Aframax, Suezmax and VLCC. The R-D diagrams were calculated for a series of 50 grounding scenarios. The diagrams were efficiently sampled using the Latin Hypercube Sampling (LHS) technique and comprehensively analysed based on ship size. Finally, the two methods were compared by statistically analysing the differences between their grounding damage indices and ultimate longitudinal strength predictions. The findings provide a useful example of how to apply the ultimate longitudinal strength analysis method to grounded ships.
\end{abstract}

KEY WORDS: Grounding damage; R-D diagram; Residual ultimate longitudinal strength; Grounding damage index; Double hull oil tankers.

\section{NOMENCLATURES}
A cross sectional area
$\mathrm{A}_{\mathrm{oi}} \quad$ original area of the inner bottom
$\mathrm{A}_{\mathrm{oo}} \quad$ original area of the outer bottom
$\mathrm{A}_{\mathrm{ri}} \quad$ reduced (damaged) area of the inner bottom
$\mathrm{A}_{\text {ro }} \quad$ reduced (damaged) area of the outer bottom
B ship breadth
b double side width
D ship's depth
h double bottom height I moment of inertia

Corresponding author: Jeom Kee Paik

e-mail:jeompaik@pusan.ac.kr

$\begin{array}{ll}\mathrm{L} & \text { ship length } \\ \mathrm{M}_{\mathrm{u}} & \text { ultimate hull girder bending moment } \\ \mathrm{M}_{\text {uо }} & \text { ultimate hull girder bending moment } \\ & \text { at intact condition } \\ \mathrm{R}^{2} & \text { coefficient of determination } \\ \mathrm{r}_{1} & \text { breadth of the bottom of the rock } \\ \mathrm{r}_{2} & \text { breadth of the tip of the rock } \\ \alpha & \text { correction factor } \\ \phi & \text { angle of the rock }\end{array}$

L ship length

$\mathrm{M}_{\mathrm{u}} \quad$ ultimate hull girder bending moment

at intact condition

breadth of the tip of the rock

angle of the rock 


\section{INTRODUCTION}

Ships are vulnerable to various accidents such as grounding, collision, fire and explosion in addition to age-related degradation such as corrosion, fatigue cracking and localised dents. This study investigates the residual ultimate longitudinal strength of double-hull oil tankers subject to grounding damage. Grounding or collision accidents continue to occur despite concerted efforts to prevent them. A recent example is the Costa Concordia cruise ship, which was grounded on 13 January 2012.

Numerous studies have been performed in relation to grounding or collision accidents, including the assessment of damage to ships (Wang et al., 2002; Paik et al., 2003; Kim, 2013), damage prediction (Simonsen and Friis-Hansen, 2000; Simonsen et al., 2009), structural consequences (Zhang, 2002; Zhang and Suzuki, 2006), hull girder collapse (Pedersen, 1994; Paik et al., 1998; Wang et al., 2000), damage scenarios (Brown, 2002; Samuelides et al., 2008; Paik et al., 2012), modelling (Tabri et al., 2009; Paik, 2007a; Paik, 2007b) and structural designs (Paik, 2003; Samuelides et al., 2009). Research on grounding accidents conducted by Pedersen (2010), Nguyen et al. (2011) and Hong and Amdahl (2012) may also be referred.

Recently, Paik et al. (2012) proposed a new concept, the R-D diagram, for accurately evaluating the safety of damaged ships using the design formula method (Paik et al., 2013) to predict the residual ultimate longitudinal strength of ships damaged by grounding. The method is based on the presumed stress distribution of the mid-ship section (Hughes and Paik, 2010).

Nevertheless, various alternative analysis methods, such as the idealized structural unit method (ISUM or SMITH method), the non-linear finite element method (NLFEM), the intelligent supersize finite element method (ISFEM) and others can also be used to identify the accuracy and efficiency of structural safety. While Paik et al. (2012) applied the design formula (analytical) method, this study focuses on the differences between the ISFEM (ALPS/HULL) (ALPS/HULL, 2012) and the design formula methods (modified Paik and Mansour method or modified P-M method) (Paik et al., 2013) in assessing the safety of damaged ship structures. The results from the two methods are compared to determine the most practical approach. Table 1 indicates the main differences between previous studies and present study. Based on the calculated results, an R-D diagram is established and the values for the grounding damage index (GDI) and residual ultimate hull girder strength are compared.

Table 1 The main differences between previous studies and the present study.

\begin{tabular}{|c|c|c|}
\hline & Previous (Paik et al., 2012) & Present \\
\hline Damage type & Grounding & Double-hull oil tankers \\
\hline Target structure & Double-hull oil tankers & Intelligent supersize FEM \\
\hline Structural analysis method & Design formula method &
\end{tabular}

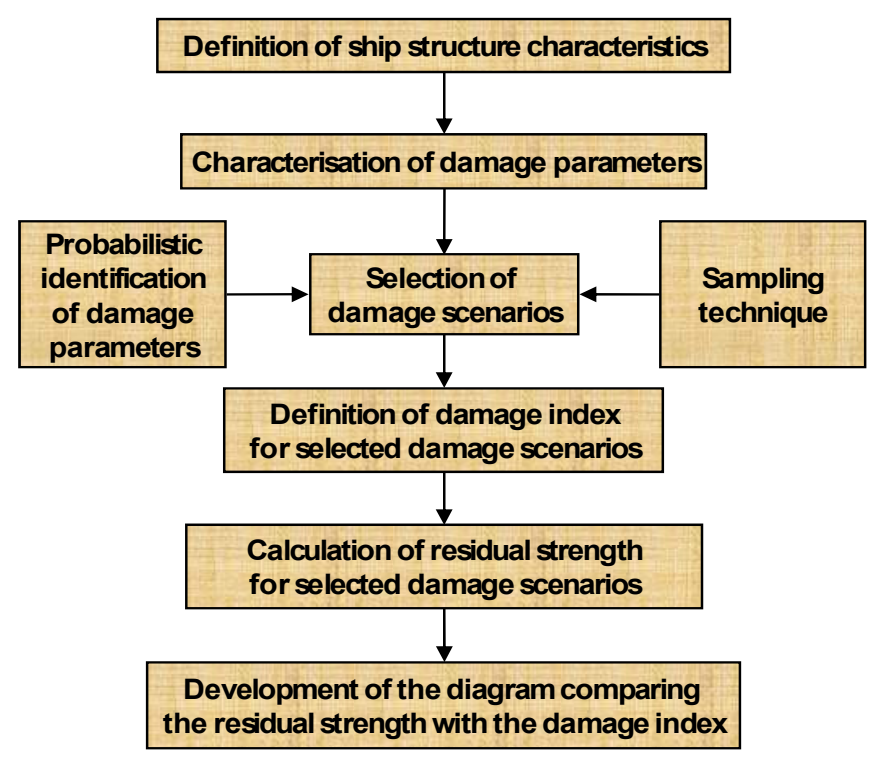

Fig. 1 The general procedure for the development of the R-D diagram (Paik et al., 2012). 


\section{PROCEDURE FOR THE DEVELOPMENT OF THE RESIDUAL STRENGTH-DAMAGE INDEX DIAGRAM}

Paik et al. (2012) proposed a new concept for evaluating damaged structures, the R-D (Residual strength - Damage index) diagram. Fig. 1 shows the general procedure for the development of an R-D diagram. Based on this procedure, R-D diagrams of double-hull oil tankers (Paik et al., 2012) using the design formula (modified P-M) method, bulk carriers (Park et al., 2012), and container ships (Kim et al., 2012a) have been established using the ISFEM (ALPS/HULL) method.

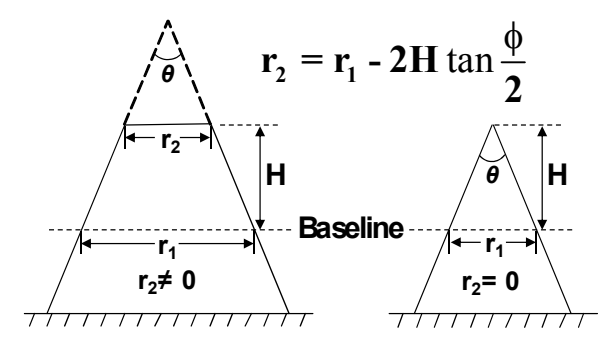

Fig. 2 Nomenclature for blunt and sharp rock shapes (Paik et al., 2012).

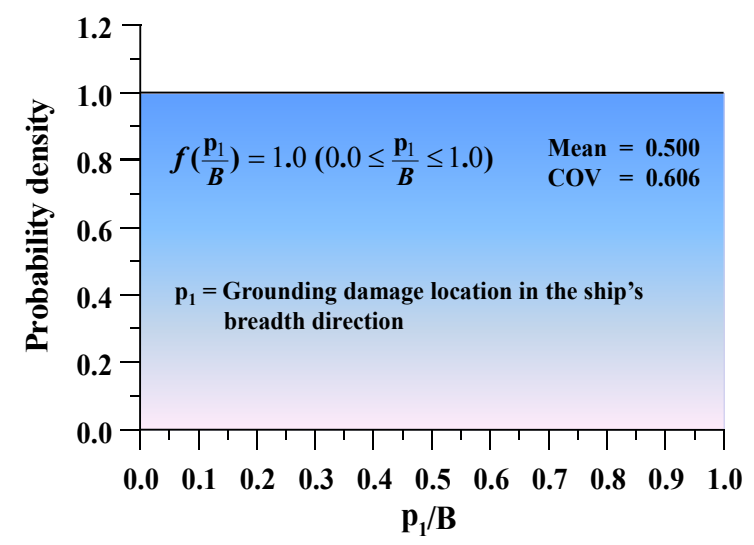

Fig. 3(a) Probability density distribution of the location of grounding damage $\left(\mathrm{p}_{1}\right)$ in the direction of the ship's breadth, normalised by ship breadth (IMO, 2003).

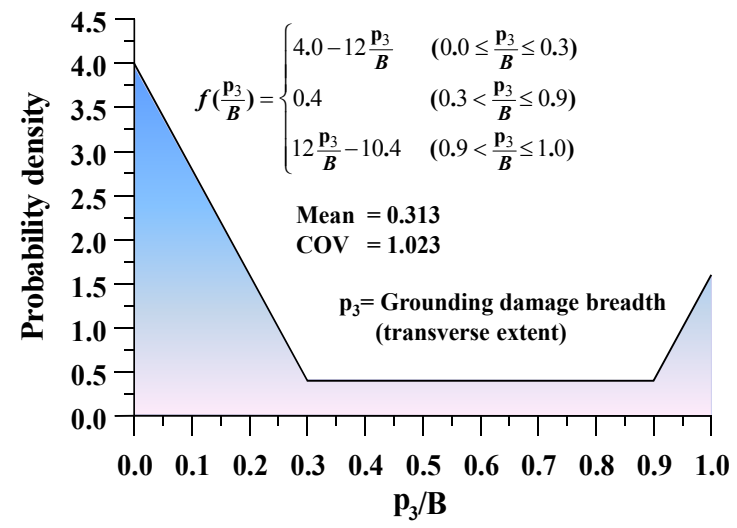

Fig. 3(c) Probability density distribution of the breadth of grounding damage $\left(\mathrm{p}_{3}\right)$, normalised by ship breadth (IMO, 2003).

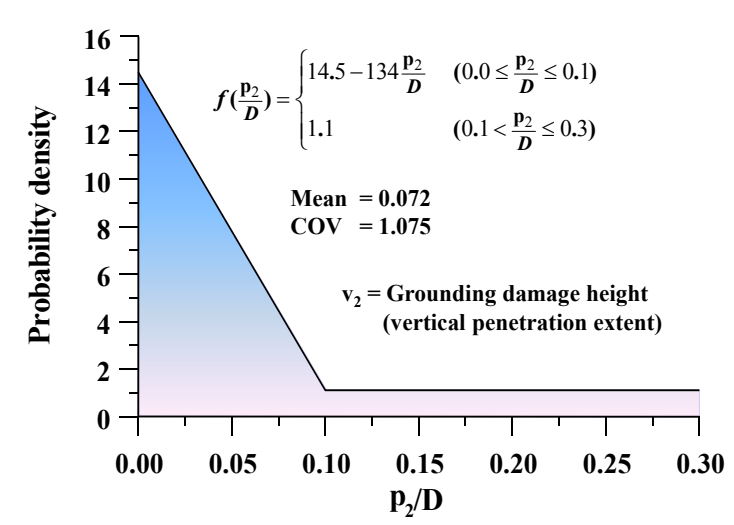

Fig. 3(b) Probability density distribution of the height of grounding damage $\left(\mathrm{p}_{2}\right)$, normalised by ship depth (IMO, 2003).

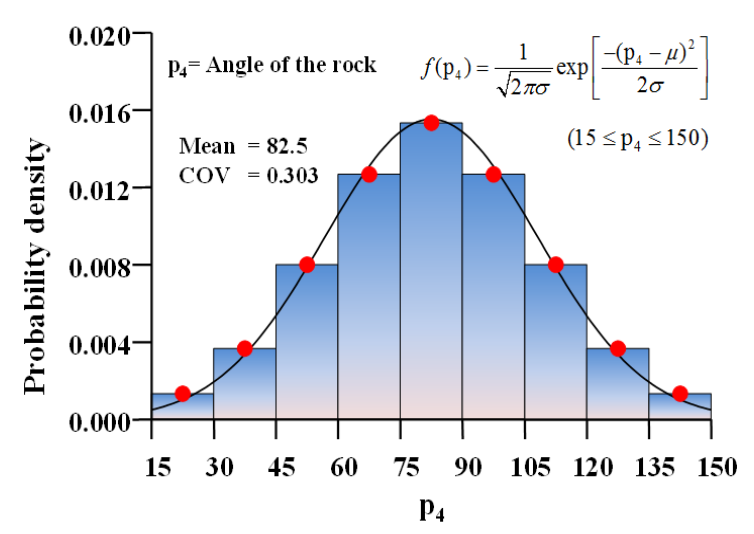

Fig. 3(d) Probability density distribution of the assumed angle of the rock $\left(\mathrm{p}_{4}\right)$ (Paik et al., 2012).

The above procedure can be summarised as follows. After defining the dimensions, geometry and material properties of the target ship structures, the grounding damage parameters should be identified as follows and as shown in Fig. 2 (Paik et al., 2012). 
- $\mathrm{p}_{1}$ : grounding location in the direction of the ship's beam.

- $\mathrm{p}_{2}$ : height $(\mathrm{H})$ of rock penetrating into the bottom of the hull in the direction of the ship's depth.

- $\mathrm{p}_{3}$ : breadth $\left(\mathrm{r}_{1}\right)$ of the bottom of the rock at the elevation corresponding to the ship's baseline and breadth $\left(\mathrm{r}_{2}\right)$ of the tip of the rock.

- $\mathrm{p}_{4}$ : angle of the rock $(\phi)$.

The previous study adopted the probability density distributions provided by the IMO (2003) as reasonable grounding damage scenarios in terms of damage location $\left(p_{1}\right)$, damage height (or penetration) $\left(p_{2}\right)$ and damage breadth $\left(p_{3}\right)$, as shown in Figs. 3(a) to (c). Figs. 3(a) to 3(c) show the IMO's probability density distributions for the grounding damage parameters and Fig. 3(d) illustrates the distribution of the assumed angles of the rocks. These figures are also employed in this study and the same assumptions used in Paik et al. (2012) are used in this study to select a reasonable number of damage scenarios using the LHS technique (Ye, 1998). This technique takes into consideration economic factors such as computational cost limitations. The expatiation of LHS is omitted, but can be found in Ye (1998). Once the grounding damage parameters (including damage location and extent) have been defined, the residual ultimate longitudinal strength analysis and identification of the grounding damage index (GDI) proceed simultaneously.

Normally, grounding in double-bottomed structures occurs in both the outer-bottom and the inner-bottom structures. Therefore, the GDI should identify the extent and location of grounding damage for both the inner and outer bottom structures, as shown in Eq. (1). It includes a correction factor $(\alpha)$ to reflect the contribution of the inner bottom structure to the ultimate longitudinal strength of the ship (Paik et al., 2012).

$$
\mathrm{GDI}=\frac{\mathrm{A}_{\mathrm{ro}}}{\mathrm{A}_{\mathrm{oo}}}+\alpha \frac{\mathrm{A}_{\mathrm{ri}}}{\mathrm{A}_{\mathrm{oi}}}
$$

\section{TARGET STUCTURES AND APPLIED METHODS}

This study examines four types of representative double-hull oil tankers: Panamax, Aframax, Suezmax and VLCC, as shown in Fig. 4 with their principal dimensions. The cross-sectional data are also presented in Table 2.

Table 2 Cross-sectional data of target structures.

\begin{tabular}{|c|c|c|c|c|}
\hline \multirow{2}{*}{ Ship type } & \multirow{2}{*}{$\mathrm{A}\left(\mathrm{m}^{2}\right)$} & \multicolumn{2}{|c|}{$\mathrm{I}\left(\mathrm{m}^{4}\right)$} & \multirow{2}{*}{ N.A. $(\mathrm{m})$} \\
\cline { 3 - 4 } & & Vertical & Horizontal & \\
\hline Panamax & 4.523 & 276.637 & 576.434 & 9.099 \\
\hline Aframax & 5.847 & 413.049 & 1316.832 & 9.548 \\
\hline Suezmax & 7.319 & 627.354 & 1980.661 & 10.377 \\
\hline VLCC & 9.593 & 1349.084 & 3861.076 & 13.218 \\
\hline
\end{tabular}

Note: $\mathrm{A}=$ sectional area, $\mathrm{I}=$ moment of inertia, N.A. = neutral axis position from baseline.

Figs. 5 (design formula method) and Figs. 6 (ISFEM) show the analysis models for double-hull oil tankers. In brief, the design formula (modified P-M) method is based on either the plate-stiffener combination (PSC) model or the plate-stiffener separation (PSS) model.

Figs. 5(a) to (d) show the PSC models for four double-hull oil tankers; the figures for the PSS model are omitted here. Design formula provides a 2-dimensional representation but ISFEM adopts a 3-dimensional representation. The important fact to note is that the assumed stress distributions are along the mid-ship section (presumed stress distribution-based method), as shown in Fig. 7. However, this method cannot deal with interactions between local and global failure. 


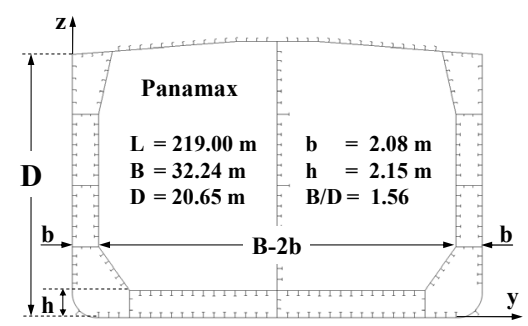

(a) Panamax class.

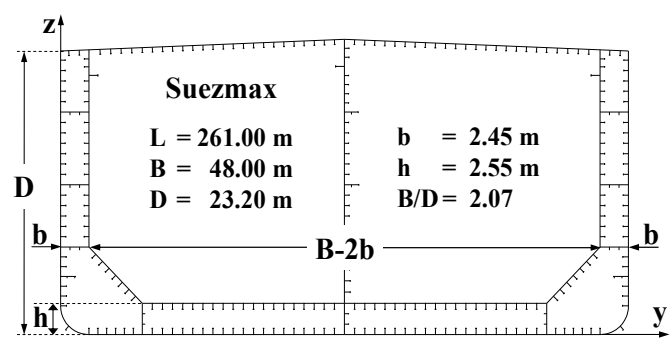

(c) Suezmax class.

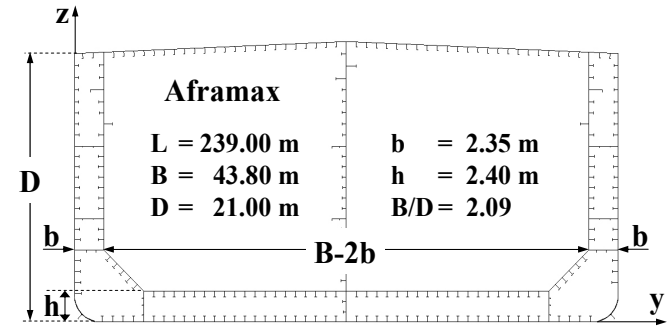

(b) Aframax class.

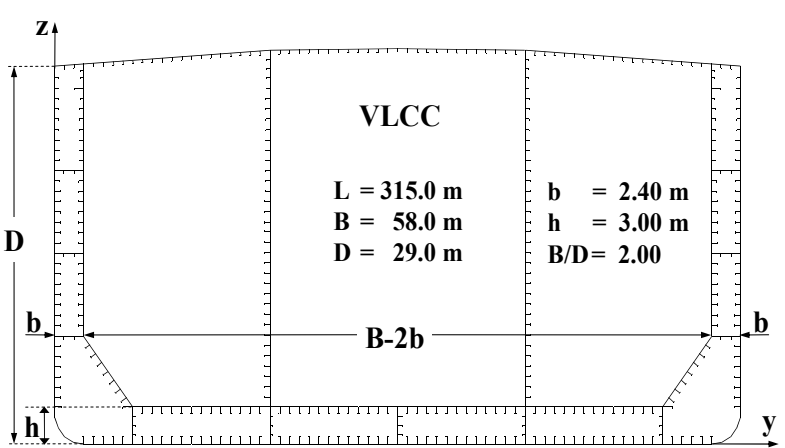

(d) VLCC class.

Fig. 4 Configuration of the mid-ship sections of four types of double-hull oil tankers and their principal dimensions (Kim et al., 2012c).

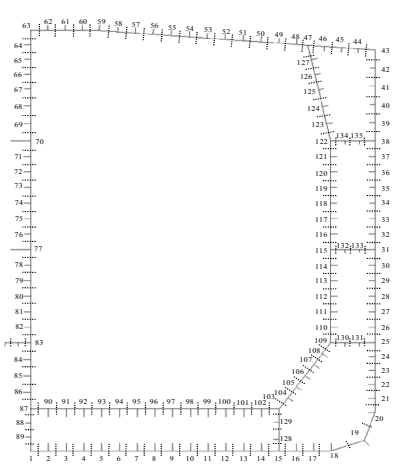

(a) Panamax class.

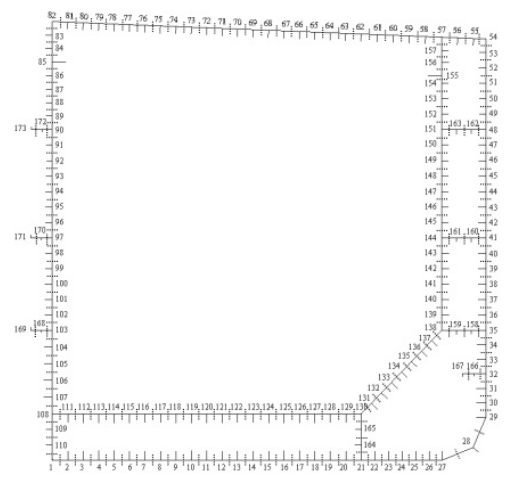

(c) Suezmax class.

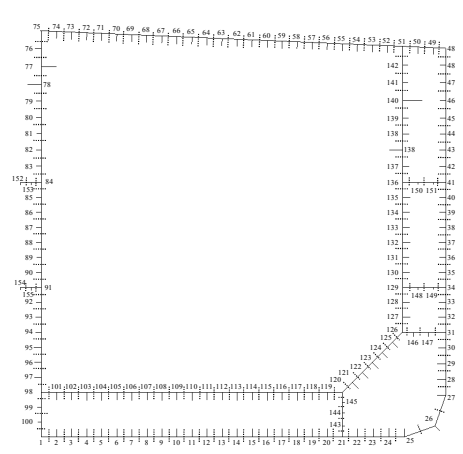

(b) Aframax class.

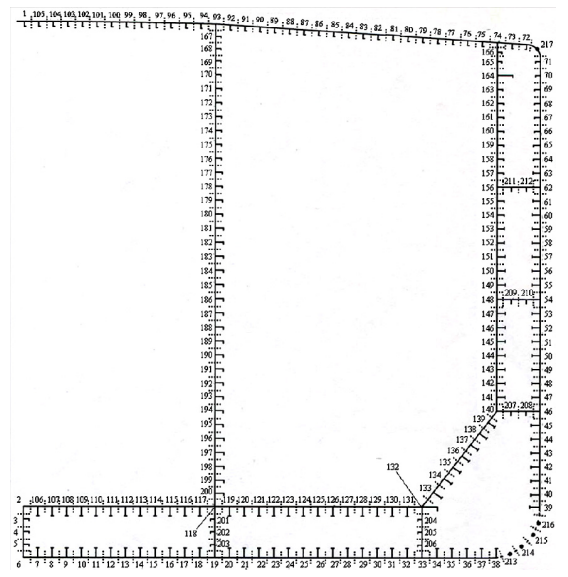

(d) VLCC class.

Fig. 5 Design formula (modified P-M) models assembled using the plate-stiffener combination (PSC) models for the four types of double-hull oil tankers (Paik et al., 2013). 


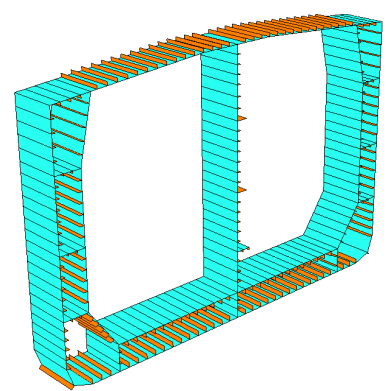

(a) Panamax class.

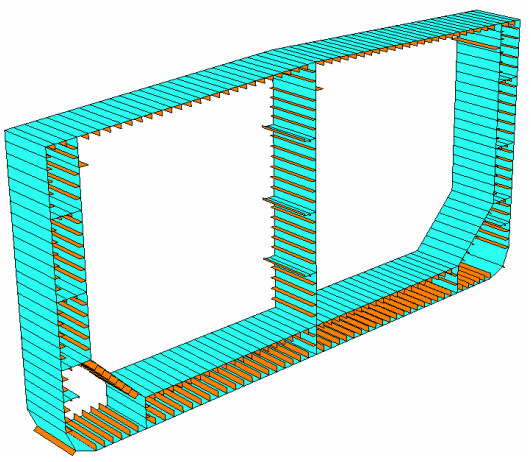

(c) Suezmax class.

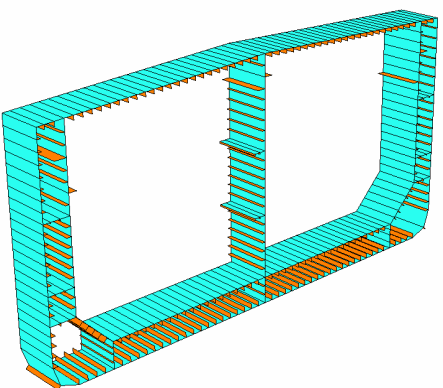

(b) Aframax class.

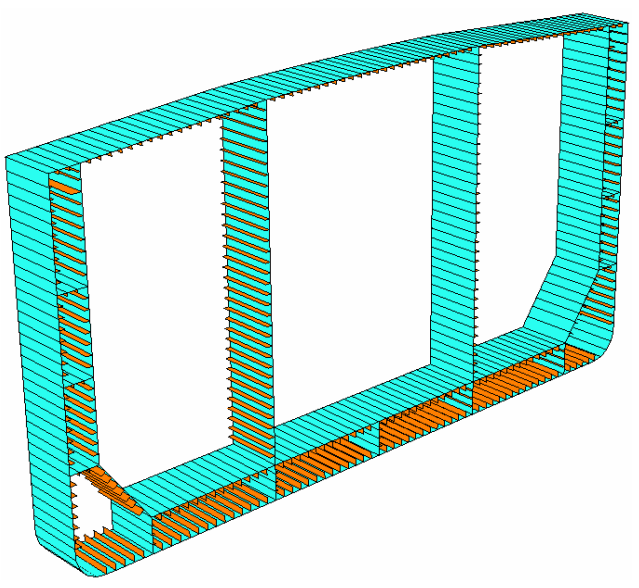

(d) VLCC class.

Fig. 6 Intelligent-supersize FEM (ALPS/HULL) models for the four types of double-hull oil tankers (ALPS/HULL, 2012).

The ISFEM method (ALPS/HULL) is only used for PSS geometric modelling and is based on a numerical formulation with closed form solutions. Therefore, it provides both 2-dimensional and 3-dimensional outputs and can deal with interactions between local and global failure. Hence, ALPS/HULL is suitable for analysing progressive hull collapse. More details on the features of these two methods can be found in Paik and Thayamballi (2003) and Hughes and Paik (2010).

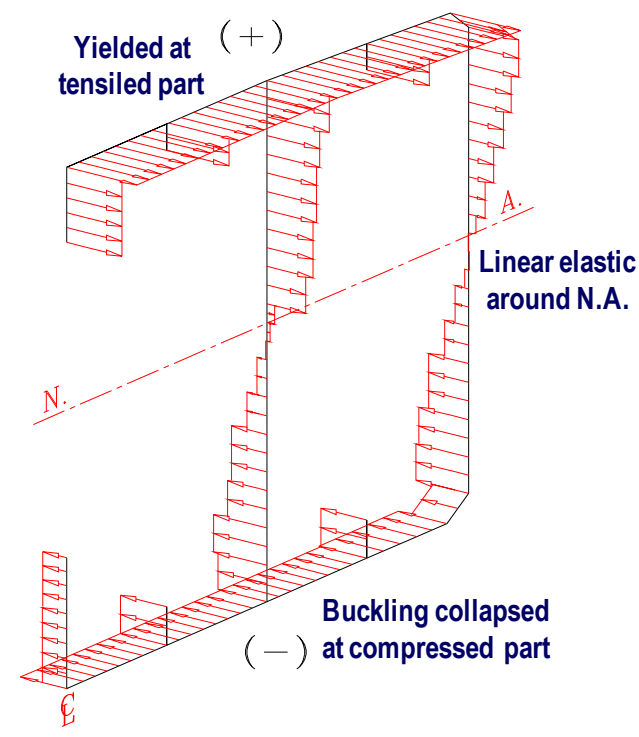

Fig. 7 Schematic view of presumed stress distribution-based method (Hughes and Paik, 2010). 


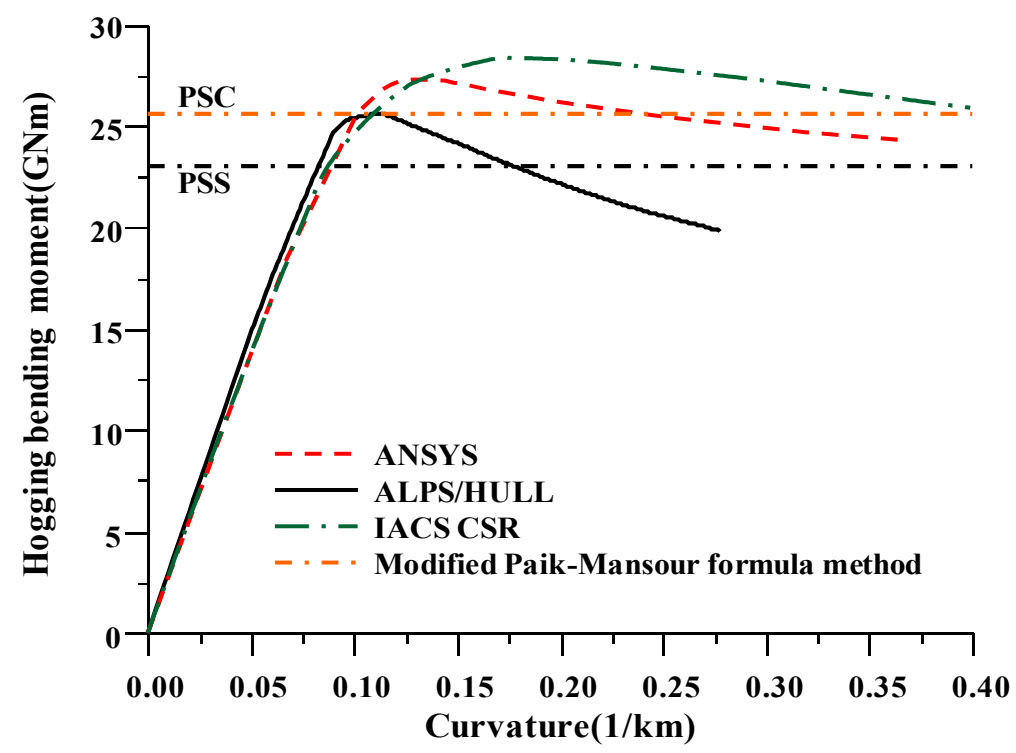

Fig. 8 Previous benchmark result for a typical double-hull VLCC as illustrated in Fig. 4(d) (Paik et al., 2013).

Before analysing the ultimate hull girder strength, benchmark research was performed for various types of vessels by Paik et al. (2013), as shown in Fig. 8. This figure shows the analysis results for a typical double-hull oil tanker. The ISFEM method (ALPS/HULL) was recently applied to various types of ship structures to analyse and identify their structural capacity (Kim et al., 2012b; 2012c; Park et al., 2012).

\section{DEVELOPMENT OF R-D DIAGRAMS AND COMPARISON OF THE TWO METHODS}

In this section, R-D diagrams are established using both the ISFEM (ALPS/HULL) and the design formula (modified P-M) method to validate the applicability of both analysis methods. Again, the analysis results are compared in a step-by-step process. The details of both methods can be found in Paik and Thayamballi (2003) and Hughes and Paik (2010). The comparison between the design formula (modified P-M) method (Paik et al., 2013) and ISFEM (ALPS/HULL) (ALPS/HULL, 2012) method begins with the following steps:

1) define the correction factor;

2) determine the GDI; and

3) establish the R-D diagram.

\section{Define the correction factor}

The correction factor $(\alpha)$ can be determined by the ratio of the slopes of the ultimate longitudinal strength behaviour in the inner and outer bottom structures for the various damage cases, as shown in Eq. (2).

$$
\alpha=\theta_{\mathrm{IB}} / \theta_{\mathrm{OB}}
$$

where $\theta_{\mathrm{IB}}$ and $\theta_{\mathrm{OB}}$ are the slopes of the ultimate longitudinal strength versus the curves of the amount of grounding damage for the respective inner and outer bottoms. Figs. 9 to 12 illustrate the comparison results for the calculated correction factors of double-hull oil tankers. 


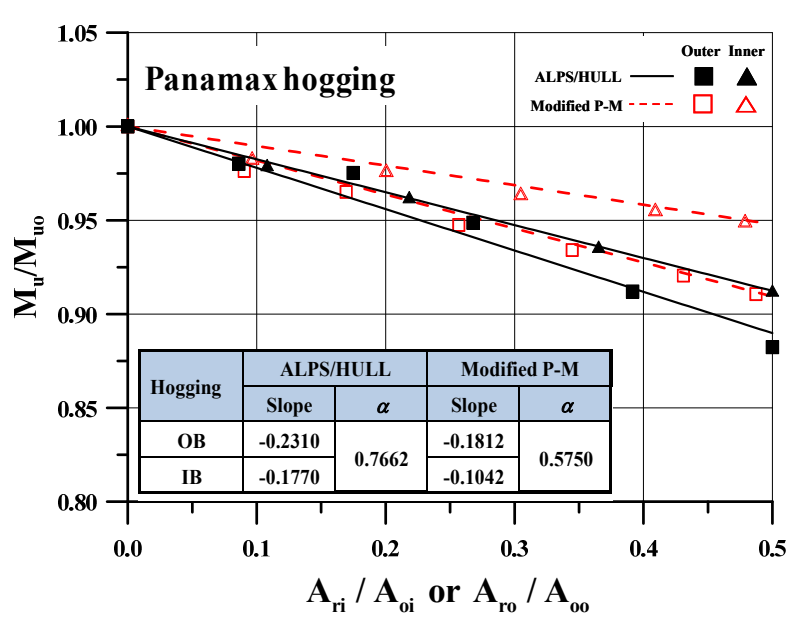

(a) Hogging condition.

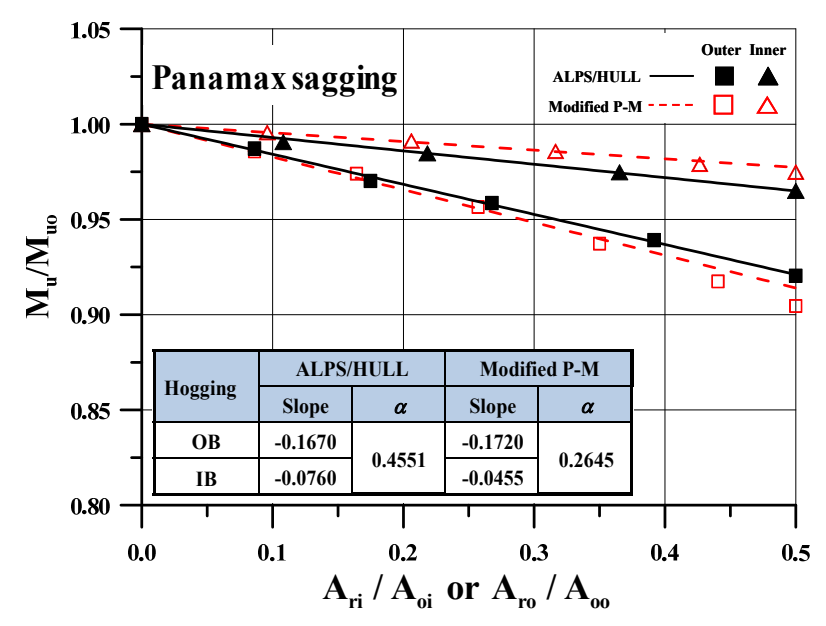

(b) Sagging condition.

Fig. 9 Variation in the ultimate longitudinal strength of a Panamax class double-hull oil tanker with the amount of grounding damage to the outer and inner bottom.

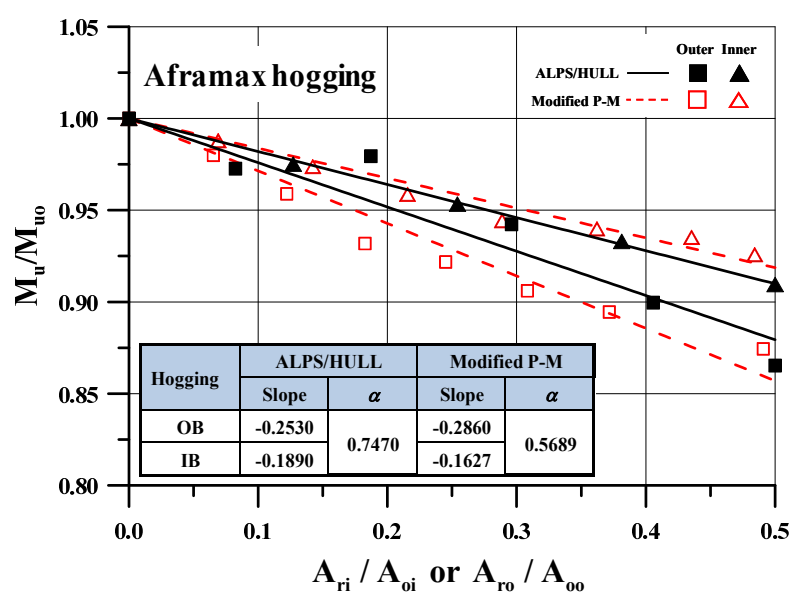

(a) Hogging condition.

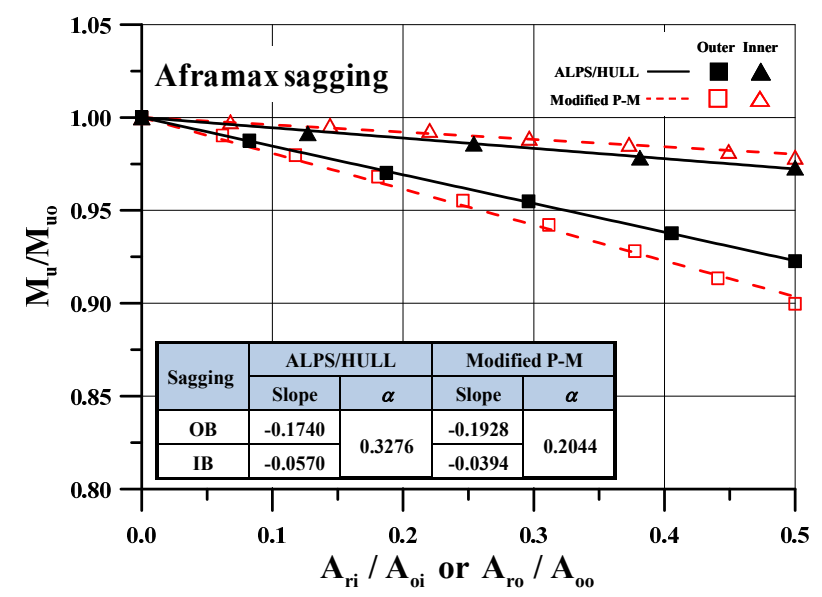

(b) Sagging condition.

Fig. 10 Variation in the ultimate longitudinal strength of an Aframax class double-hull oil tanker with the amount of grounding damage to the outer and inner bottom.

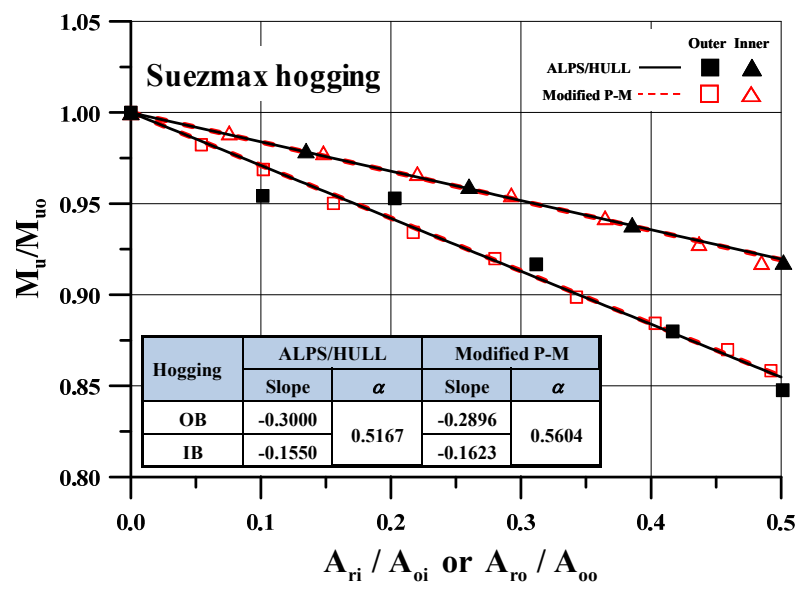

(a) Hogging condition.

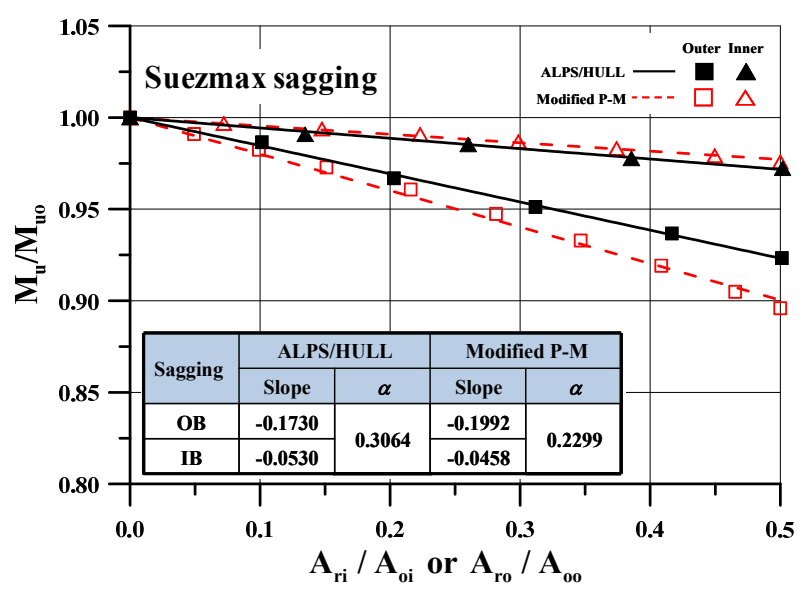

(b) Sagging condition.

Fig. 11 Variation in the ultimate longitudinal strength of a Suezmax class double-hull oil tanker with the amount of grounding damage to the outer and inner bottom. 


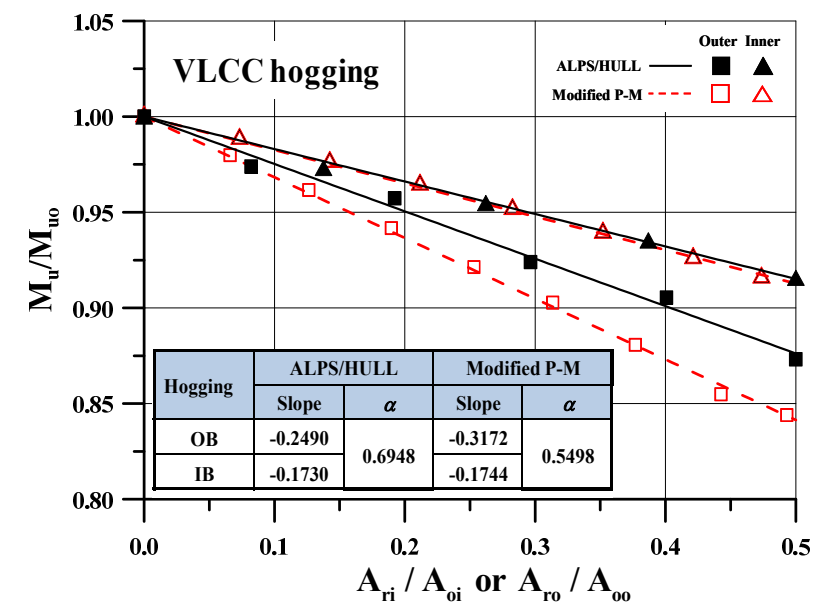

(a) Hogging condition.

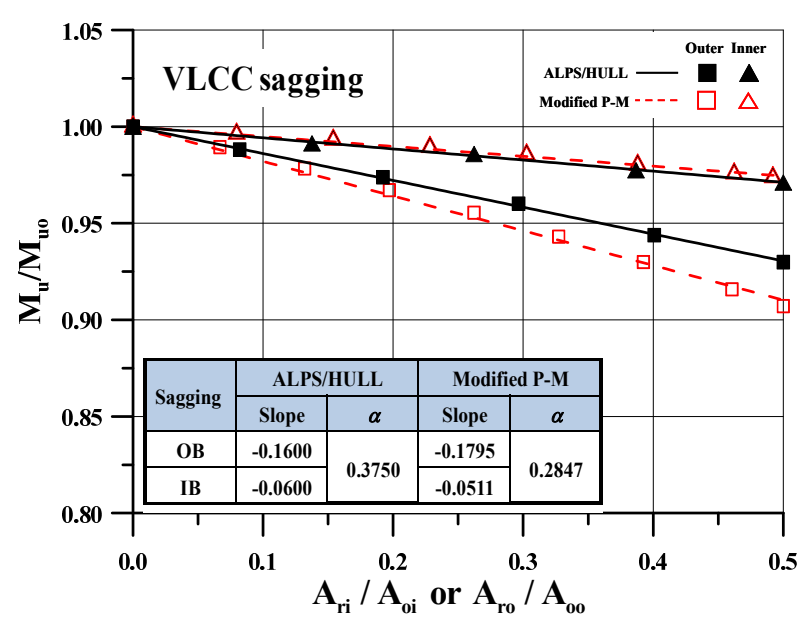

(b) Sagging condition.

Fig. 12 Variation in the ultimate longitudinal strength of a VLCC class double-hull oil tanker with the amount of grounding damage to the outer and inner bottom.

Table 3 shows the correction factors obtained from the results of Figs. 9 to 12. Generally, the trend of the correction factors produced by the ISFEM (ALPS/HULL) method show an upward tendency compared with the design formula (modified P-M) method.

Table 3 Comparison of correction factors.

\begin{tabular}{|c|c|c|c|c|}
\hline \multirow{2}{*}{ Correction factor } & \multicolumn{2}{|c|}{ Hogging } & \multicolumn{2}{c|}{ Sagging } \\
\cline { 2 - 5 } & ALPS / HULL & Modified P-M & ALPS / HULL & Modified P-M \\
\hline Panamax & 0.7662 & 0.5750 & 0.4551 & 0.2645 \\
\hline Aframax & 0.7470 & 0.5689 & 0.3276 & 0.2044 \\
\hline Suezmax & 0.5167 & 0.5604 & 0.3064 & 0.2299 \\
\hline VLCC & 0.6948 & 0.5498 & 0.3750 & 0.2847 \\
\hline
\end{tabular}

Note: ALPS/HULL = analysis method based on ISFEM, Modified P-M = analysis method based on design formula method.

\section{Determine the GDI}

Using the principal dimensions illustrated in Fig. 4, together with the IMO's probability density distributions and assumptions of the rock's shape using the LHS technique, four types of grounding damage parameters for 50 grounding damage scenarios are defined and shown in Table 4. The grounding damage indices for 50 grounding damage scenarios are calculated based on the obtained damaged parameters under vertical bending moments based on the values from Eqs. (1) and (2) and Table 3. The results for the calculation of values are covered in the discussion section.

\section{Establish the R-D diagram}

In this section, R-D diagrams are developed based on the calculated residual ultimate longitudinal strength and grounding damage indices. Figs. 13(a) to (d) show the developed R-D diagrams obtained using a curve-fitting method. Figs. 14 and 15 show the R-D diagrams for all double-hull oil tankers using both the ISFEM (ALPS/HULL) and the design formula (modified P-M) method. 
Table 4 The four grounding damage parameters for 50 grounding damage scenarios (Paik et al., 2012).

\begin{tabular}{|c|c|c|c|c|}
\hline Scenario & $\mathrm{p}_{1}$ & $\mathrm{p}_{2}$ & $\mathrm{p}_{3}$ & $\mathrm{p}_{4}$ \\
\hline 1 & $0.010 \mathrm{~B}$ & $0.080 \mathrm{D}$ & $0.144 \mathrm{~B}$ & 103.0 \\
\hline 2 & $0.030 \mathrm{~B}$ & $0.017 \mathrm{D}$ & $0.918 \mathrm{~B}$ & 88.3 \\
\hline 3 & $0.050 \mathrm{~B}$ & $0.071 \mathrm{D}$ & $0.064 \mathrm{~B}$ & 56.2 \\
\hline 4 & $0.070 \mathrm{~B}$ & $0.019 \mathrm{D}$ & $0.018 \mathrm{~B}$ & 124.0 \\
\hline 5 & $0.090 \mathrm{~B}$ & $0.200 \mathrm{D}$ & $0.777 \mathrm{~B}$ & 101.3 \\
\hline 6 & $0.110 \mathrm{~B}$ & $0.016 \mathrm{D}$ & $0.008 \mathrm{~B}$ & 74.0 \\
\hline 7 & $0.130 \mathrm{~B}$ & $0.026 \mathrm{D}$ & $0.945 \mathrm{~B}$ & 80.6 \\
\hline 8 & $0.150 \mathrm{~B}$ & $0.182 \mathrm{D}$ & $0.127 \mathrm{~B}$ & 116.5 \\
\hline 9 & $0.170 \mathrm{~B}$ & $0.273 \mathrm{D}$ & $0.427 \mathrm{~B}$ & 84.4 \\
\hline 10 & $0.190 \mathrm{~B}$ & $0.219 \mathrm{D}$ & $0.046 \mathrm{~B}$ & 96.6 \\
\hline 11 & $0.210 \mathrm{~B}$ & $0.109 \mathrm{D}$ & $0.195 \mathrm{~B}$ & 71.3 \\
\hline 12 & $0.230 \mathrm{~B}$ & $0.044 \mathrm{D}$ & $0.090 \mathrm{~B}$ & 81.9 \\
\hline 13 & $0.250 \mathrm{~B}$ & $0.011 \mathrm{D}$ & $0.023 \mathrm{~B}$ & 72.7 \\
\hline 14 & $0.270 \mathrm{~B}$ & $0.008 \mathrm{D}$ & $0.083 \mathrm{~B}$ & 99.7 \\
\hline 15 & $0.290 \mathrm{~B}$ & $0.291 \mathrm{D}$ & $0.013 \mathrm{~B}$ & 62.0 \\
\hline 16 & $0.310 \mathrm{~B}$ & $0.024 \mathrm{D}$ & $0.104 \mathrm{~B}$ & 79.3 \\
\hline 17 & $0.330 \mathrm{~B}$ & $0.075 \mathrm{D}$ & $0.327 \mathrm{~B}$ & 51.4 \\
\hline 18 & $0.350 \mathrm{~B}$ & $0.033 \mathrm{D}$ & $0.034 \mathrm{~B}$ & 53.9 \\
\hline 19 & $0.370 \mathrm{~B}$ & $0.052 \mathrm{D}$ & $0.058 \mathrm{~B}$ & 48.5 \\
\hline 20 & $0.390 \mathrm{~B}$ & $0.040 \mathrm{D}$ & $0.477 \mathrm{~B}$ & 138.7 \\
\hline 21 & $0.410 \mathrm{~B}$ & $0.042 \mathrm{D}$ & $0.577 \mathrm{~B}$ & 93.7 \\
\hline 22 & $0.430 \mathrm{~B}$ & $0.255 \mathrm{D}$ & $0.070 \mathrm{~B}$ & 87.0 \\
\hline 23 & $0.450 \mathrm{~B}$ & $0.067 \mathrm{D}$ & $0.980 \mathrm{~B}$ & 26.2 \\
\hline 24 & $0.470 \mathrm{~B}$ & $0.004 \mathrm{D}$ & $0.237 \mathrm{~B}$ & 106.7 \\
\hline 25 & $0.490 \mathrm{~B}$ & $0.028 \mathrm{D}$ & $0.003 \mathrm{~B}$ & 85.7 \\
\hline 26 & $0.510 \mathrm{~B}$ & $0.049 \mathrm{D}$ & $0.183 \mathrm{~B}$ & 92.3 \\
\hline 27 & $0.530 \mathrm{~B}$ & $0.095 \mathrm{D}$ & $0.377 \mathrm{~B}$ & 63.7 \\
\hline 28 & $0.550 \mathrm{~B}$ & $0.005 \mathrm{D}$ & 0.827B & 111.1 \\
\hline 29 & $0.570 \mathrm{~B}$ & $0.021 \mathrm{D}$ & $0.153 \mathrm{~B}$ & 113.6 \\
\hline 30 & $0.590 \mathrm{~B}$ & $0.038 \mathrm{D}$ & $0.052 \mathrm{~B}$ & 75.4 \\
\hline 31 & $0.610 \mathrm{~B}$ & $0.128 \mathrm{D}$ & $0.877 \mathrm{~B}$ & 60.2 \\
\hline 32 & $0.630 \mathrm{~B}$ & $0.057 \mathrm{D}$ & $0.994 \mathrm{~B}$ & 83.1 \\
\hline 33 & $0.650 \mathrm{~B}$ & $0.086 \mathrm{D}$ & $0.097 \mathrm{~B}$ & 41.0 \\
\hline 34 & $0.670 \mathrm{~B}$ & $0.006 \mathrm{D}$ & $0.257 \mathrm{~B}$ & 89.6 \\
\hline 35 & $0.690 \mathrm{~B}$ & $0.164 \mathrm{D}$ & $0.221 \mathrm{~B}$ & 78.0 \\
\hline 36 & $0.710 \mathrm{~B}$ & $0.022 \mathrm{D}$ & $0.135 \mathrm{~B}$ & 66.9 \\
\hline 37 & $0.730 \mathrm{~B}$ & $0.060 \mathrm{D}$ & $0.727 \mathrm{~B}$ & 119.8 \\
\hline 38 & $0.750 \mathrm{~B}$ & $0.036 \mathrm{D}$ & $0.162 \mathrm{~B}$ & 76.7 \\
\hline 39 & $0.770 \mathrm{~B}$ & $0.064 \mathrm{D}$ & $0.076 \mathrm{~B}$ & 58.2 \\
\hline 40 & $0.790 \mathrm{~B}$ & $0.032 \mathrm{D}$ & $0.207 \mathrm{~B}$ & 68.4 \\
\hline 41 & $0.810 \mathrm{~B}$ & $0.002 \mathrm{D}$ & $0.119 \mathrm{~B}$ & 95.1 \\
\hline 42 & $0.830 \mathrm{~B}$ & $0.014 \mathrm{D}$ & $0.677 \mathrm{~B}$ & 98.1 \\
\hline 43 & $0.850 \mathrm{~B}$ & $0.146 \mathrm{D}$ & $0.111 \mathrm{~B}$ & 65.3 \\
\hline 44 & $0.870 \mathrm{~B}$ & $0.012 \mathrm{D}$ & $0.964 \mathrm{~B}$ & 129.8 \\
\hline 45 & $0.890 \mathrm{~B}$ & $0.030 \mathrm{D}$ & $0.040 \mathrm{~B}$ & 35.2 \\
\hline 46 & $0.910 \mathrm{~B}$ & $0.047 \mathrm{D}$ & $0.527 \mathrm{~B}$ & 104.8 \\
\hline 47 & $0.930 \mathrm{~B}$ & $0.009 \mathrm{D}$ & $0.029 \mathrm{~B}$ & 108.8 \\
\hline 48 & $0.950 \mathrm{~B}$ & $0.237 \mathrm{D}$ & $0.627 \mathrm{~B}$ & 69.9 \\
\hline 49 & $0.970 \mathrm{~B}$ & $0.001 \mathrm{D}$ & $0.172 \mathrm{~B}$ & 45.2 \\
\hline 50 & $0.990 \mathrm{~B}$ & $0.054 \mathrm{D}$ & $0.285 \mathrm{~B}$ & 91.0 \\
\hline
\end{tabular}




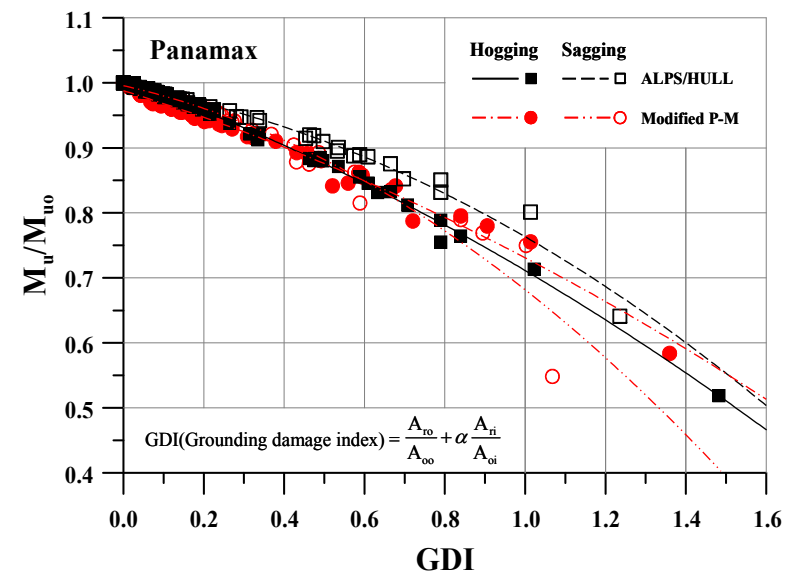

(a) Panamax class.

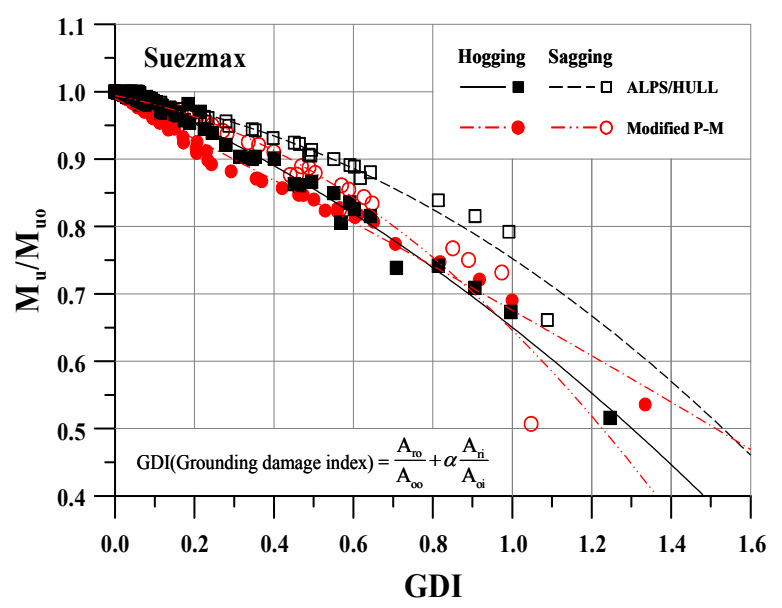

(c) Suezmax class.

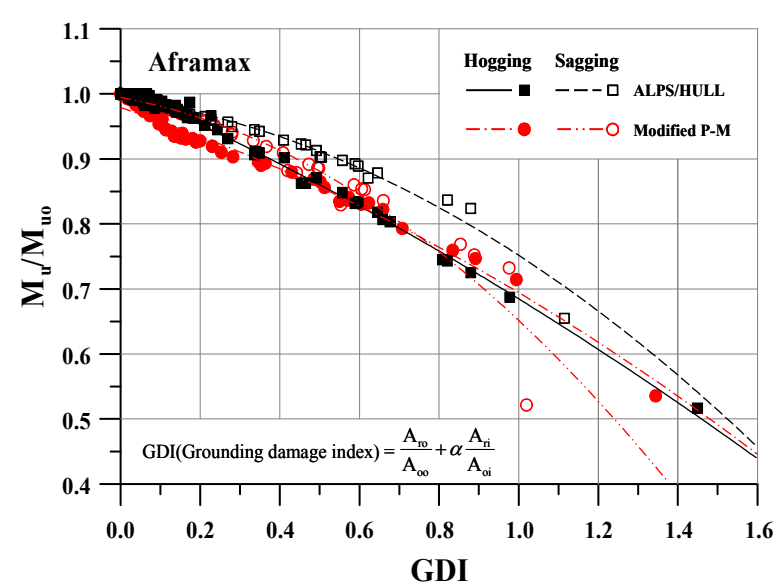

(b) Aframax class.

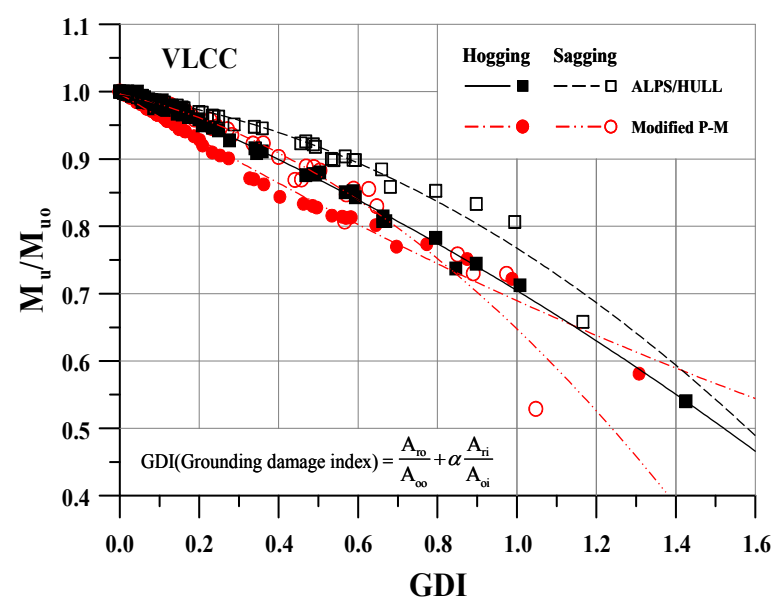

(d) VLCC class.

Fig. 13 The R-D diagrams for the double-hull oil tanker.

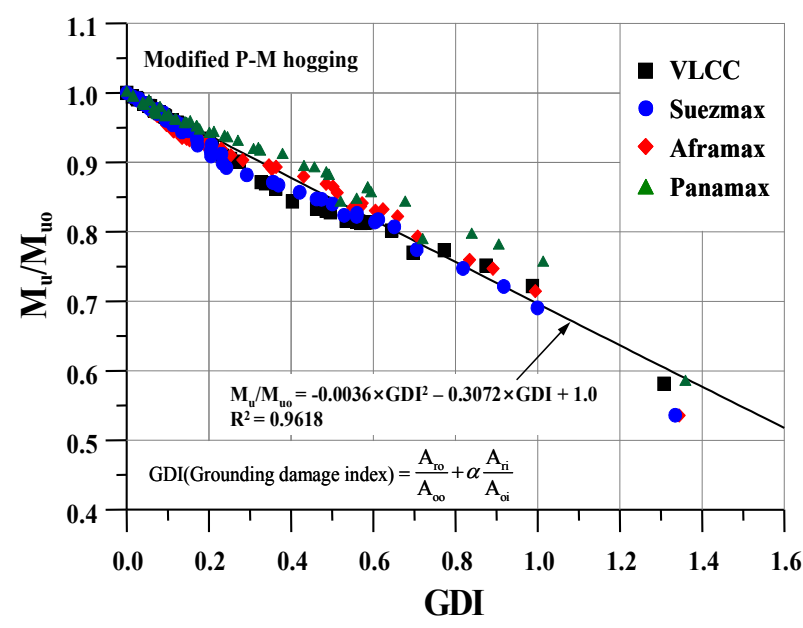

(a) Design formula (modified P-M)

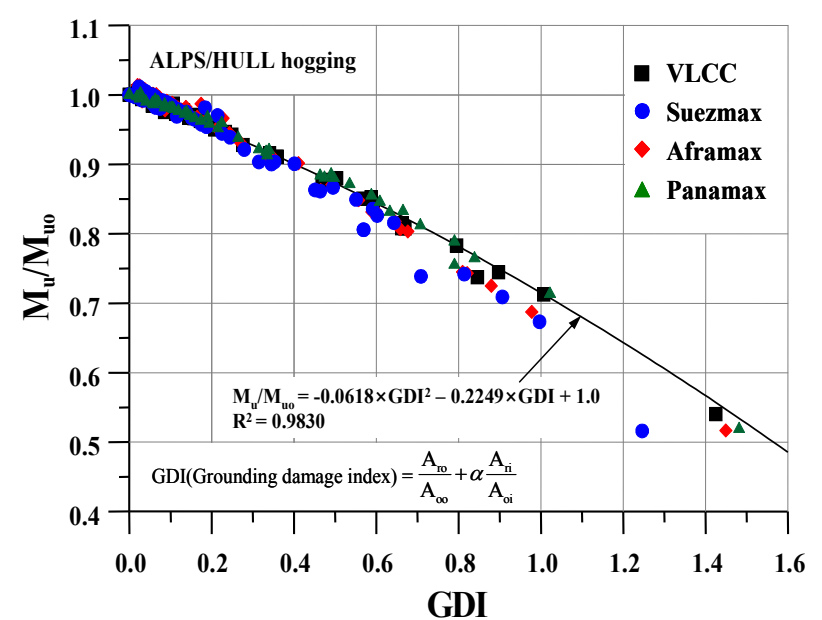

(b) Intelligent-supersize FEM (ALPS/HULL). method (Paik et al., 2012).

Fig. 14 The obtained R-D diagrams for the double-hull oil tankers under the hogging bending moment. 


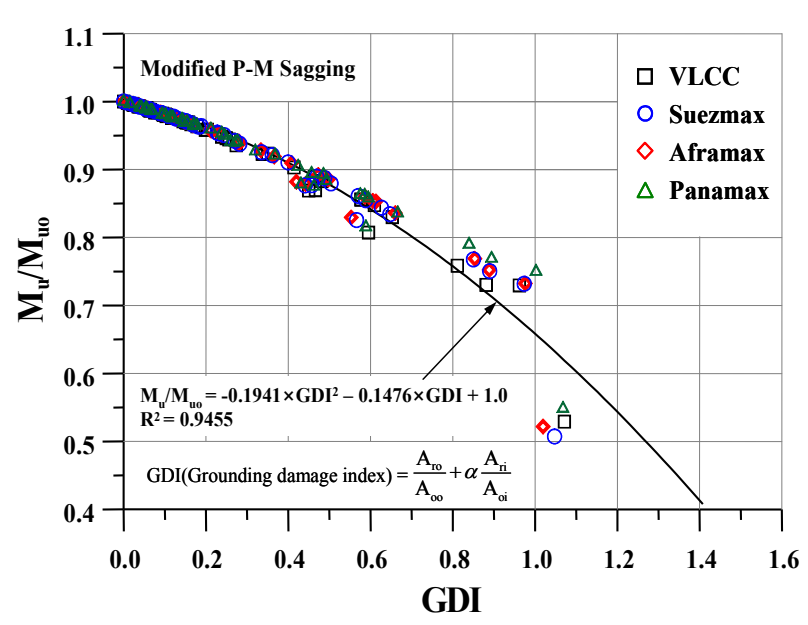

(a) Design formula (modified P-M) method (Paik et al., 2012).

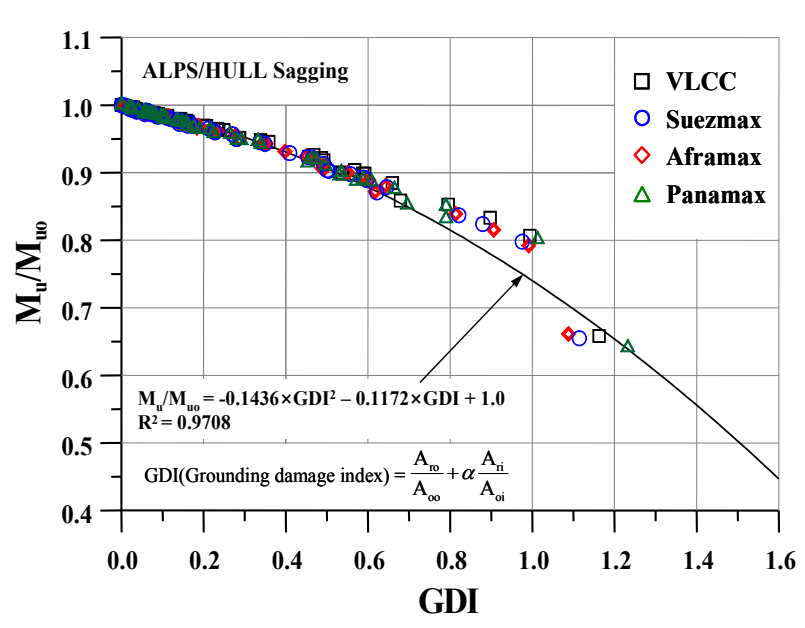

(b) Intelligent-supersize FEM (ALPS/HULL).

Fig. 15 The obtained R-D diagrams for the double-hull oil tankers under the sagging bending moment.

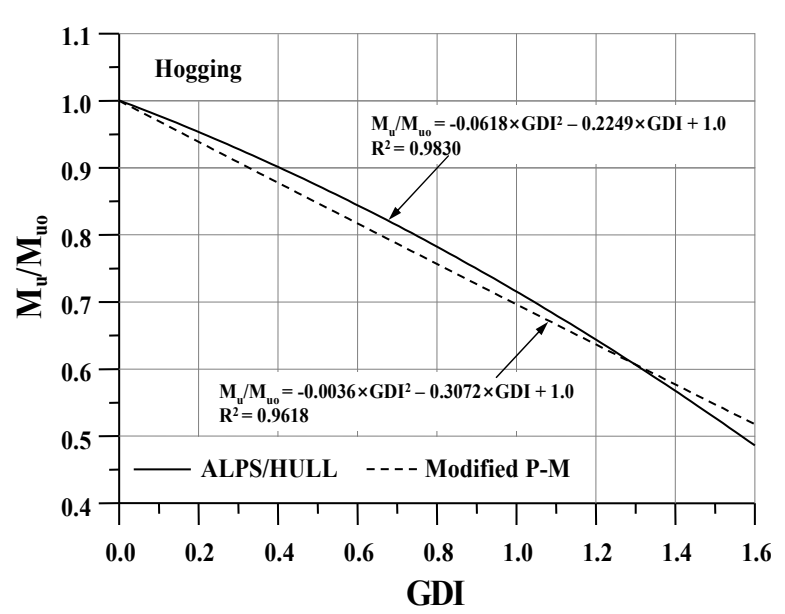

(a) Hogging condition.

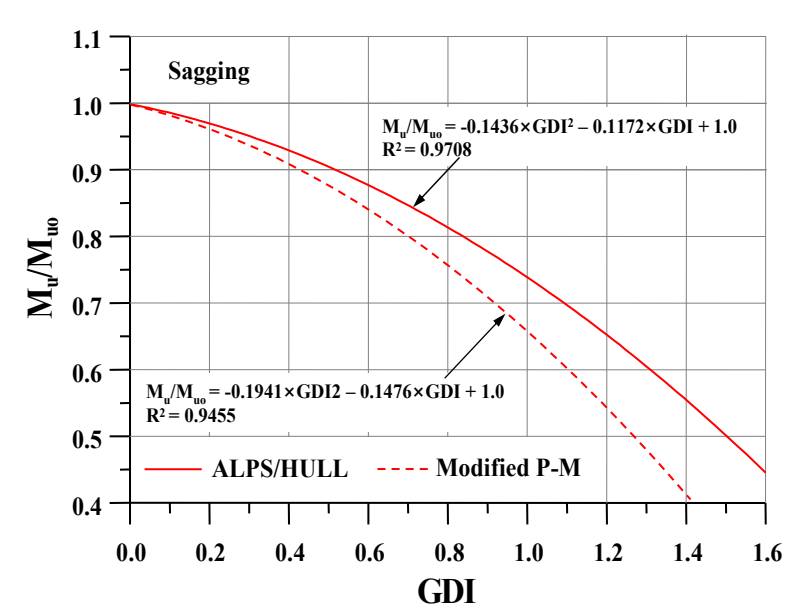

(b) Sagging condition.

Fig. 16 Comparison between the R-D diagrams for double-hull oil tankers produced by the intelligent-supersize FEM (ALPS/HULL) and those produced by the design formula (modified P-M) method.

Generally, the R-D diagrams obtained by the design formula (modified P-M) method underestimate the residual ultimate longitudinal strength of double-hull oil tankers in both the hogging and sagging conditions, compared with ISFEM (ALPS/ HULL). The results can be found in Figs. 16(a) and (b).

\section{DISCUSSIONS}

Figs. 17 and 18 show the statistical results based on the obtained outputs. Two parameters, the GDI and the residual ultimate bending moment $\left(\mathrm{M}_{\mathrm{u}}\right)$, were assessed by considering the vertical hogging and sagging moments. The aim of this study was to compare the residual ultimate bending moment capacity calculated by these two methods. The grounding damage indices were also compared, as shown in Figs. 17(a) and (b). As mentioned in Paik et al. (2013), oil tanker structures can be modelled using the design formula (modified P-M) method using the plate-stiffener separation model (PSS), and those under a hogging moment can be modelled using the plate-stiffener combination (PSC) model.

The ISFEM (ALPS/HULL) method uses the PSS modelling technique. A comparison of the results obtained by these two techniques under the same conditions is shown in Figs. 17(b) and 18(b). PSS modelling is adopted with the design formula (modified P-M) method and ISFEM (ALPS/HULL) in sagging conditions. 


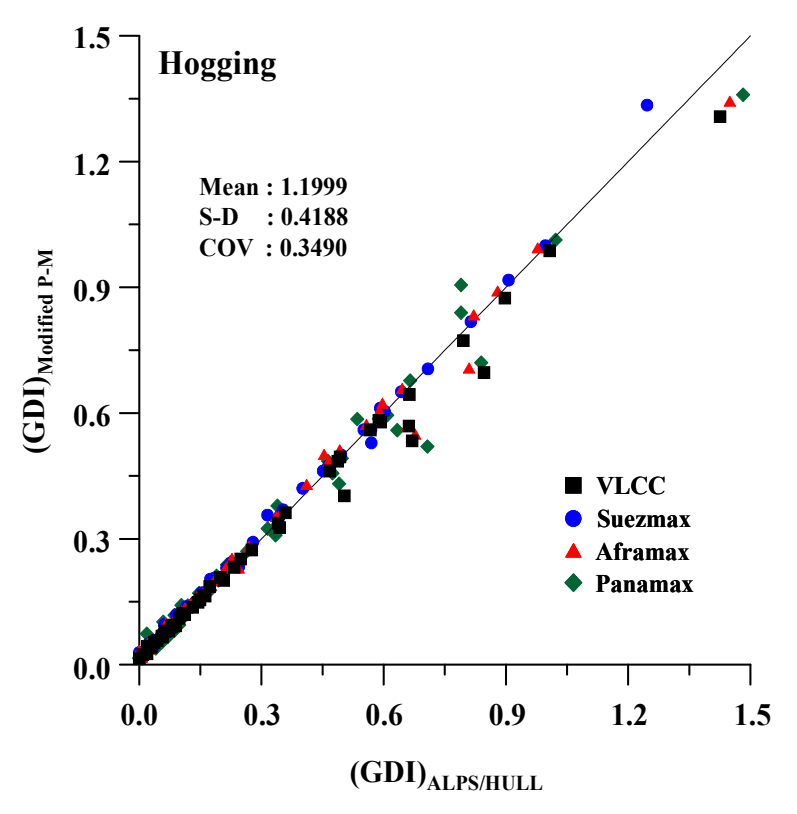

(a) Hogging condition.

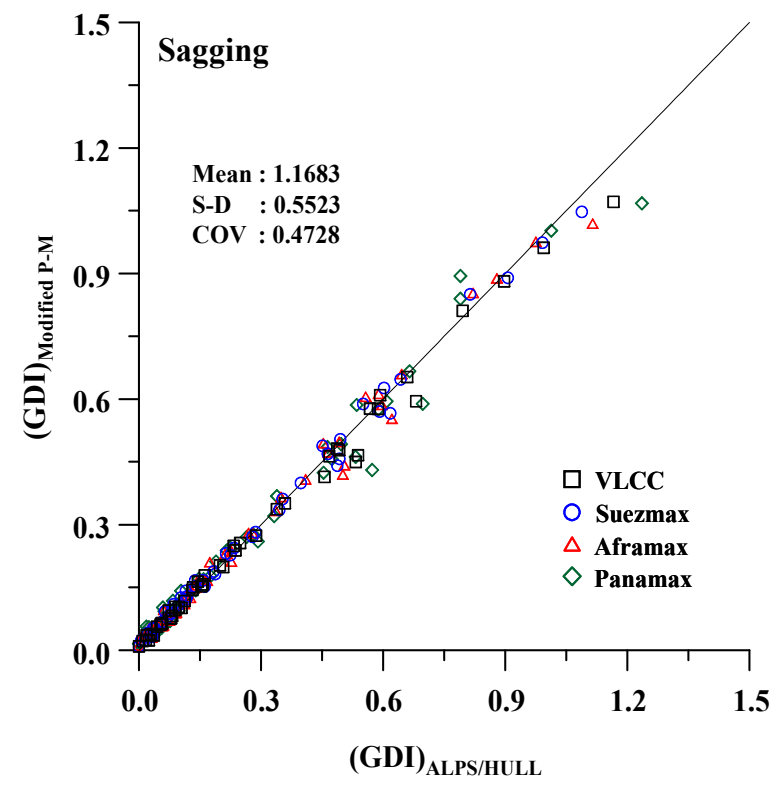

(b) Sagging condition.

Fig. 17 The deviation between the grounding damage indices (GDI) obtained by the design formula method and the intelligent-supersize FEM.

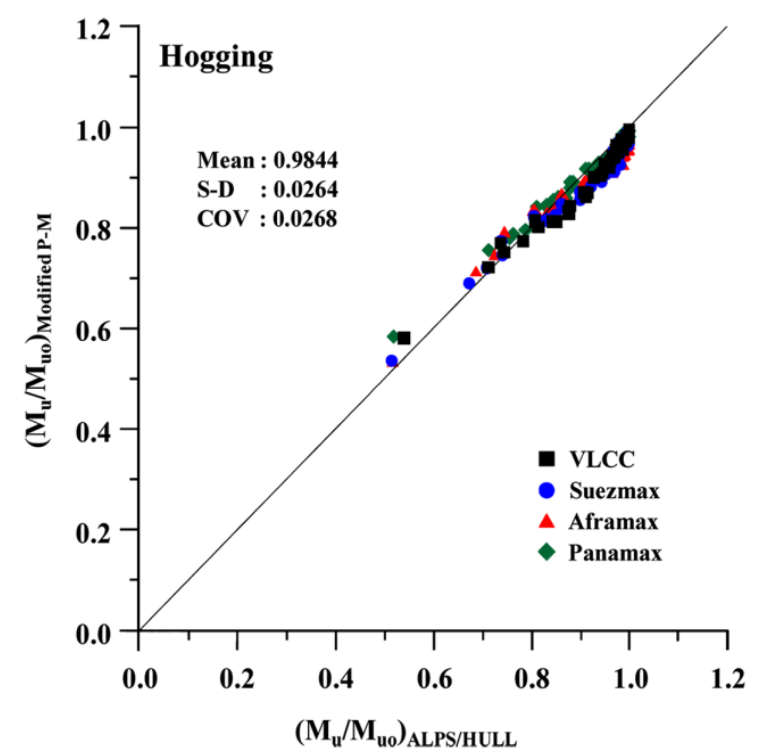

(a) Hogging condition.

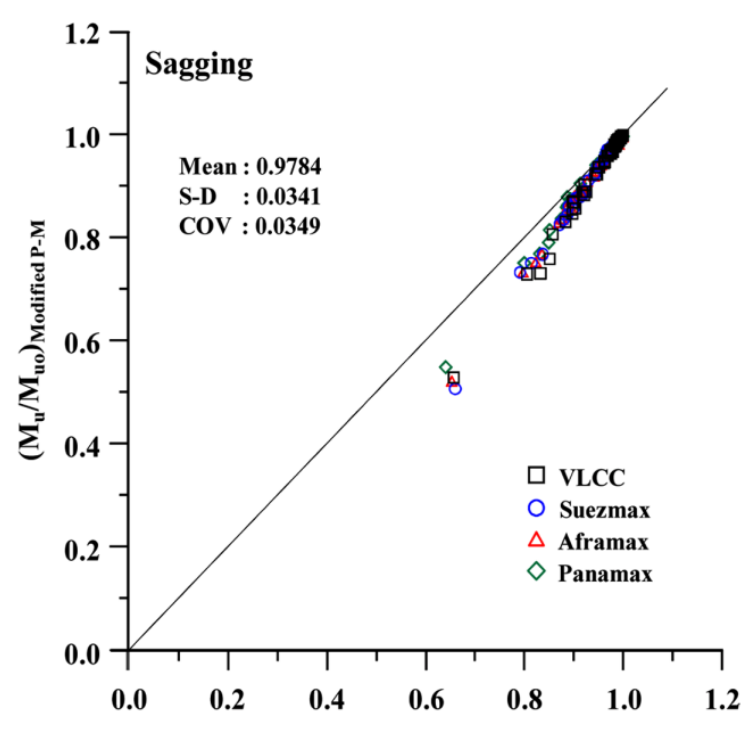

(b) Sagging condition.

Fig. 18 The deviation between the residual ultimate longitudinal strength analysed by the design formula method and the intelligent-supersize FEM.

In contrast, Figs. 17(a) and 18(a) illustrate the results of the analysis based on PSC modelling (design formula method) and PSS modelling (ISFEM). In this case, the results are somewhat different. The results for the sagging moment conditions are more general using both analysis methods.

Fig. 17(b) indicates that ISFEM produces a better result than the design formula method. However, the results of the design formula method are pessimistic from a designer's perspective.

Finally, both of these two methods can be applied to analyse grounding damage to double-hull oil tanker structures. The comparison results will be useful for assessing the safety of damaged ships using the abovementioned methods. 


\section{CONCLUDING REMARKS}

Ship grounding accidents frequently occur despite continual efforts to prevent them. To produce salvage plans or to save human lives, safety assessment guidelines that include reliable accident scenarios are needed.

Various methods for estimating the safety of damaged ship structures have been proposed. Among them, analysis methods (e.g., the design formula method) and numerical methods (e.g., intelligent supersize FEM) have been compared to determine the residual ultimate longitudinal strength of grounded ship structures.

This study compared and verified the applicability of the abovementioned methods. To select realistic grounding damage scenarios, the Residual ultimate longitudinal strength - grounding Damage index (R-D) diagram approach was applied to the ISFEM (ALPS/HULL) and design formula (modified P-M) method. The obtained R-D diagrams were compared in terms of their residual ultimate longitudinal strength and grounding damage index (GDI) predictions under vertical bending moments. Future research will also consider collision damage, among other types.

\section{ACKNOWLEDGEMENTS}

This study was undertaken by Lloyd's Register Foundation (LRF) Research Centre of Excellence (The Ship and Offshore Research Institute) at Pusan National University, Korea. Lloyd's Register Foundation supports the advancement of engineeringrelated education, and funds research and development that enhances safety of life at sea, on land and in the air. The research was supported by the Basic Science Research Program through the National Research Foundation of Korea (NRF) and funded by the Ministry of Education, Science, and Technology (Grant no.: K20903002030-12E0100-04610). The first author (D.K. Kim) is now with the Graduate School of Engineering Mastership (GEM) at Pohang University of Science and Technology (POSTECH).

\section{REFERENCES}

ALPS/HULL, 2012. A computer program for progressive collapse analysis of ship hulls. DRS Defense Solutions, Advanced Marine Technology Center, Stevensvill, MD, USA (www.proteusengineering.com, www.maestromarine.com).

Brown, A.J., 2002. Collision scenarios and probabilistic collision damage. Marine Structures, 15(4-5), pp.335-364.

Hong, L. and Amdahl, J., 2012. Rapid assessment of ship grounding over large contact surfaces. Ships and Offshore Structures, 7(1), pp.5-19.

Hughes, O.F. and Paik, J.K., 2010. Ship structural analysis and design. The Society of Naval Architects and Marine Engineers, New Jersey, USA.

IMO, 2003. Revised interim guidelines for the approval of alternative methods of design and construction of oil tankers. Marine Environment Protection Committee of the Organization by Resolution MEPC 110(49), International Maritime Organization, London, UK.

Kim, D.K., 2013. Condition assessment of damaged ships and ship-shaped offshore structures. PhD. Pusan National University.

Kim, D.K., Kim, H.B., Zhang, X., Pedersen, P.T., Kim, M.S. and Paik, J.K., 2012a. Development of a relationship between residual ultimate longitudinal strength and grounding damage index diagram for container ships. Proceedings of $31^{\text {st }}$ International Conference on Ocean, Offshore and Artic Engineering (OMAE 2012). Rio de Janeiro, Brazil 1-6 July 2012.

Kim, D.K., Park, D.K., Kim, H.B., Seo, J.K., Kim, B.J., Paik, J.K. and Kim, M.S., 2012b. The necessity of applying the common corrosion addition rule to container ships in terms of ultimate longitudinal strength. Ocean Engineering, 49, pp.43-55.

Kim, D.K., Park, D.K., Park, D.H., Kim, H.B., Kim, B.J., Seo, J.K. and Paik, J.K., 2012c. Effect of corrosion on the ultimate strength of double hull oil tankers - Part II: hull girders. Structural Engineering and Mechanics, 42(4), pp.531549.

Nguyen, T.H., Garrè, L., Amdahl, J. and Leira, B.J., 2011. Monitoring of ship damage condition during stranding. Marine Structures, 24(3), pp.261-274. 
Paik, J.K., 2003. Innovative structural designs of tankers against ship collisions and grounding: A recent state-of-the-art review. Marine Technology, 40(1), pp.25-33.

Paik, J.K., 2007a. Practical techniques for finite element modeling to simulate structural crashworthiness in ship collisions and groundings (Part I: Theory). Ships and Offshore Structures, 2(1), pp.69-80.

Paik, J.K., 2007b. Practical techniques for finite element modeling to simulate structural crashworthiness in ship collisions and groundings (Part II: Verification). Ships and Offshore Structures, 2(1), pp.81-85.

Paik, J.K., Amdahl, J., Barltrop, N., Donner, E.R., Gu, Y., Ito, H., Ludolphy, H., Pedersen, P.T., Rohr, U. and Wang, G., 2003. Collision and grounding, Final report of ISSC V.3. International Ship and Offshore Structures Congress. San Diego, USA 11-15 August 2003.

Paik, J.K., Kim, D.K., Park, D.H., Kim, H.B. and Kim, M.S., 2012. A new method for assessing the safety of ships damaged by grounding. International Journal of Maritime Engineering, 154(A1), pp.1-20.

Paik, J.K., Kim, D.K., Park, D.H., Kim, H.B., Mansour, A.E. and Caldwell, J.B., 2013. Modified Paik-Mansour formula for ultimate strength calculations of ship hulls. Ships and Offshore Structures, in-press (http://dx.doi.org/10.1080/ 17445302. 2012. 676247).

Paik, J.K. and Thayamballi, A.K., 2003. Ultimate limit state design of steel-plated structures. John Wiley \& Sons, Chichester, UK.

Paik, J.K., Thayamballi, A.K. and Yang, S.H., 1998. Residual strength assessment of ships after collision and grounding. Marine Technology, 35(1), pp.38-54.

Park, D.H., Kim, D.K., Kim, H.B., Zhang, X.M., Seo, J.K., Kim, B.J., Paik, J.K. and Kim, M.S., 2012. A study on estimation of ultimate residual longitudinal strength of grounded commercial ships. The Annual Spring Meeting of Society of Naval Architects of Korea. Daegu, Korea 31 May-1 June.

Pedersen, P.T., 1994. Ship grounding and hull-girder strength. Marine Structures, 7(1), pp.1-29.

Pedersen, P.T., 2010. Review and application of ship collision and grounding analysis procedures. Marine Structures, 23 (3), pp.241-262.

Samuelides, M.S., Tabri, K., Incecik, A. and Dimou, D., 2008. Scenarios for the assessment of the collision behavior of ships. International Shipbuilding Progress, 55(1-2), pp.145-162.

Samuelides, M.S., Ventikos, N.P. and Gemelos, I.C., 2009. Survey on grounding incidents: Statistical analysis and risk assessment. Ships and Offshore Structures, 4(1), pp.55-68.

Simonsen, B.C. and Friis-Hansen, P., 2000. Theoretical and statistical analysis of ship grounding accidents. Journal of Offshore Mechanics and Arctic Engineering, Transactions of the ASME, 122(3), pp.200-207.

Simonsen, B.C., Törnqvist, R. and Lützen, M., 2009. A simplified grounding damage prediction method and its application in modern damage stability requirements. Marine Structures, 22(1), pp.62-83.

Tabri, K., Broekhuijsen, J., Matusiak, J. and Varsta, P., 2009. Analytical modeling of ship collision based on full scale experiments. Marine Structures, 22(1), pp.42-61.

Wang, G., Arita, K. and Liu, D., 2000. Behavior of a double hull in a variety of stranding or collision scenarios. Marine Structures, 13(3), pp.147-187.

Wang, G., Spencer, J. and Chen, Y., 2002. Assessment of a ship's performance in accidents. Marine structures, 15(4-5), pp. 313-333.

Ye, K.Q., 1998. Orthogonal column latin hypercubes and their application in computer experiments. Journal of the American Statistical Association, 93(444), pp.1430-1439.

Zhang, A. and Suzuki, K., 2006. Dynamic finite element simulations of the effect of selected parameters on grounding test results of bottom structures. Ships and Offshore Structures, 1(2), pp.117-125.

Zhang, S., 2002. Plate tearing and bottom damage in ship grounding. Marine Structures, 15(2), pp.101-117. 